\title{
Place-Based Approach: a US-EU Comparison
}

\author{
Saverio Alessandro Falcomatà ${ }^{1, a}$, Teresa Nucera ${ }^{1, b}$ and Leonarda Tripodi ${ }^{1, c}$ \\ ${ }^{1}$ Mediterranea University of Reggio Calabria - PAU - Department of Heritage, Architecture, Urban \\ Planning, Via Salita Melissari - 89124, Reggio di Calabria, Italy \\ aalessandro.falcomata@unirc.it, bteresa.nucera@unirc.it, leonarda.tripodi@unirc.it
}

\begin{abstract}
Keywords: Place-Based Approach, Equity Distribution, Local Development, Community Led Local Development (CLLD), Smart Specialization $\left(\mathrm{S}^{3}\right)$.
\end{abstract}

\begin{abstract}
A basic requirement to achieve economic development within a State or a union of states is to reduce spatial inequalities between the different regions and cities. Both in the European Union and in the United States, development budget funds are assigned to local development strategies. In this perspective, the place-based approach furthers regional development by tailoring policies to the specific economic and social contexts. American and European case studies reveal strengths and weaknesses of policies involved in the local development process while pursuing the spatial equity distribution principle. The multidisciplinary approach of the CLUDs project, focusing on urban and territorial planning, urban management and local development, better analyzes issues through a methodological approach based on case studies. According to the CLUDs project, American case studies such as Dudley Street, Boston MA and Washington Gateway Main Street, Boston MA, reveal a consolidate recourse to corporations, organizations and institutions in order to implement the place-based initiatives. Conversely, European case studies such as Berlin-Brandenburg, Germany and West Midlands, United Kingdom and others, denoted an ad-hoc "place-based" practice, with a wider scope of application. Final observations enable to implement the theoretical knowledge on the places-based approach as a driver to thrive local development.
\end{abstract}

\section{Introduction}

In the European perspective the place-based approach finds its main target in the spatialization of the investments, sponsored by the cohesion policy. However, a policy unclear and generalist in its essence has led increasingly to the necessity of shifting the focus more on a contextual analysis, in order to identify all those competitive niches in which to allocate these European funds.

As Fabrizio Barca argues, in the place-based development policy, where space-aware policy interventions are aimed at improving opportunities and changing economic institutions, a distinction is called for between the two objectives of these enhanced opportunities:

1. the efficiency objectives, i.e. achieving a fuller utilization of economic potential of all places;

2. the equity objectives, i.e. achieving socially acceptable standard of living and reducing disparities, independently of where people live [1]. Barca defines the place-based approach as an advanced approach for delivering public goods and services, addressing multiple dimensions of social inclusion [1]. The basic assumption is that the place-based approach improves performance of development policies (by stimulating endogenous development potentials and catering policy to local circumstances) and properly outlines role of territorially bound assets (factors) such as settlement structure, accessibility infrastructure etc. in pursuing key development goals at EU and national level. Therefore, a place-based approach opposites to sectorial approach that usually neglects synergies between different types of public interventions and makes policy integration difficult and cumbersome at the local and regional level. The key elements of place-based approach [1] are:

1. All the necessary ingredients of the place-based approach are in place.

2. There is no uniform template of the place-based approach. Countries' approaches differ.

3. Territory can be considered as an important topic for cross-governance dialogue within the place based frame. 
4. Some elements of the place-based approach needs strengthening, mainly: the way territorial knowledge is collected, multi-level governance dialogue and its instruments.

5. While territorialisation of some policies that have already strongly benefit out of it should be continued (e.g. transport policy, environment policy, urban policy, regional policy, spatial policy), there is a need to extend the place-based approach to some other policies with the substantial potential for territorialisation, mainly: R\&D policy, business policy, employment policy, education policy, and so on. According to Tomaney the place-based approach is an economic development strategy that includes all "attempts to tap into economic potential that remains unused and not identifiable to outside agencies, so that all parts of cities and regions can contribute to National development" [2].

The American perspective, as represented by the CLUDs case studies analysis, describes the place-based approach as a community-oriented intervention which relies upon partnerships with residents and local businesses to pursue community development objectives. Place-based process allow managers to interact with people who live, work and play in a place and who care about it. This is important because planning in itself is a place-making-creating process. Place-based planning engages the public and enables an understanding of the interaction of people and places [3].

\section{Place-Based: drivers and tools}

In the perspective of the European cohesion policy, the concept of spatial equity distribution refers to the huge disparities existing between EU Member States. As Philippe Martin points out, "certain economic agents - be they workers or consumers - are not mobile and are not therefore condemned to live in poor or declining regions from which the mobile factors (capital and highly skilled workers) have departed. Because of the lower labor demand in such regions, real wages will adjust downward or, if real wages do not adjust because of labor market rigidities, unemployment will increase" [4]. Spatial equity distribution and local development can be considered the main drivers of the place-based approach. The notion of equity "is about ensuring equal opportunities for individuals irrespective of where they live" [1]. This implies a balanced correlation between the distribution of people and goods, services and facilities in the territory. In other words, an equilibrium in the spatial distribution of urban areas. Therefore, spatial equity distribution deals with all strategies aimed at "increasing the potential of the economic and the institutional resources of all towns, thus strengthening their assets (...) in order to ensure equal opportunities based on those towns' outstanding activities and competitiveness" [5]. In line with the Commission's proposal, the place-based approach provides specific tools "to promote the development of local and sub-regional approaches, in particular via community-led local development [...]" [6].

Community-led local development (from now on CLLD) is a tool applied at a local level helping to involve citizens in the analysis, evaluation and responding to the social, environmental and economic challenges faced today. CLLD requires much time and effort on the part of individuals, but for relatively small financial investments [7]. Besides, it can have a marked impact on people's lives generating new ideas and commitments being turned into practice. CLLD can be a particularly powerful and effective tool, especially in times of crisis. With the help of this tool, local communities can take concrete steps and measures promoting economic development and stability in the world, can become smarter, more sustainable and more inclusive, in line with the Europe 2020 Strategy.

The two important principles of CLLD include "sub-regional areas" (local territorial approach, Article 28.1a), where funds are concentrated on poor regions and less-developed countries, and "innovation" (Article 28.1d), where the method generates new ways of thinking and doing in a local context, including new markets, new products, services, ways of working and social innovation. Furthermore, the CLLD tool can be used in different areas, such as rural areas, fisheries and coastal areas, cities and urban areas combating unemployment and promoting social cohesion in those regions.

The policy aim of Smart specialization strategy, included in Europe 2020, is becoming more popular and widely used in the modern society. Different regions are characterized by the lack of the 
proper budget and scarce resources needed for its efficacy and success. The use and employment of the Smart specialization strategy will help to organize investment in the needed areas allocating funds based on the external influences, such as competition between companies, and the connections between various industries operated in the same country [8]. The Smart specialization strategy should be based on the regional analysis and technological advances having the aim to reduce continuous inefficiencies in various fields, as well as social exclusion. The purpose of this concept is to establish EU interventions differentiating between member-countries and different companies operated in this or that field. Competitiveness, technological advances and other characteristic features should be taken into consideration promoting the future success and efficacy in this field. The identification of the major sectors promoting the regions' economic development and stability as well as the continuous investment in private areas is an important process. Strategy development and innovative practices will help to increase the efficacy and success of the chosen regions. In general, the application of the smart specialization strategies $\left(\mathrm{S}^{3}\right)$ should be associated with the proper use of EU Structural Funds and the reduction of the differences between various European regions following the same standards and capabilities.

Following a place-based approach [9] the American practices rely on legally-existing entities such as Foundations, Community Development Financial Institutions, Community Development Partnerships and Community Development Corporations.

The Community Development Financial Institutions (CDFIs) are non- governmental entities defined as financial institutions with a primary mission of community development, providing development services and accountability to its community.

The Community Development Partnerships (CDPs) are efforts typically led by a CDC, providing partnerships with residents and local businesses to pursue community economic development objectives.

The Community Development Corporations (CDCs) are non-profit organized at the local level and responsible for the development of housing, business and commercial activity or service and programming provisions. The criteria and measures for evaluating CDCs appeal to different capacities: resource capacity (raising funds, managing them and deploying them appropriately); organizational capacity (the depth, skills, and experience of board and staff members); programmatic capacity (housing, commercial, real estate development/enterprise, or social service delivery and/or advocacy); networking capacity (the ability to build networks with other organizations-linkages); political capacity (CDCs influence with government officials at all levels, CDCs legitimacy within the community it serves). CDCs develop and revise strategic plans, try to anticipate changes in city policies; they work hard to earn and maintain the support of residents, maintaining frequent and open communication with support community and respond to problems building trust but also educate [10]

\section{A US-EU Comparison}

From the comparison between American Case Studies [11] and European Case Studies [12] it is possible to draw some conclusions: the reduction of spatial inequalities among different cities is essential to achieve and make the economic development of a city or state stable, while the strategies of local development are responsible for the development budget funds. The main difference between US and EU lies in the scope of application: in the first case the interventions are neighborhood-focused, whereas in the second the approach is broader, usually regional-oriented. Therefore, while the EU situation could be improved by providing enhancement strategies, the US context is more balanced, where the weaknesses are hard to indicate, and thus the strategies should be developed concerning the maintenance and improvement of the efficiency of the current situation. The EU may still achieve a proper level of economic development, making changes in the policy to implement successful place-based actions, which will satisfy the EU, and which will make the policy areas stable [1]. Case studies analyzed within the CLUDs project confirm that the place-based approach can contribute to foster job creation and job retention, especially where the local 
development process is activated by different stakeholders, including private and governmental organizations. For instance, the area of training and education is a strong one at both sides. The gap between the federal and state policies can be filled due to the use of certain programs, what lead to the cooperation between the citizens in the neighborhood regions. It is a great factor, leading to the implementation of good place-based practices. In order to grasp the similarities and disparities in the way the US and EU implement their place based practices, it may be useful to resort to some basic evaluation questions (such as those listed below), which allow to make effective comparisons between the two different approaches and to formulate hypotheses about the type of policy interventions governments need to carry out in order to scale up interventions, both at local and regional levels.

Table 1.

\begin{tabular}{|c|c|c|c|c|}
\hline & Policy Area & Evaluation questions & $U S$ & $E U$ \\
\hline 1 & $\begin{array}{l}\text { Local } \\
\text { development } \\
\text { - Community } \\
\text { involvement }\end{array}$ & $\begin{array}{l}\text { - How do community } \\
\text { residents participate the } \\
\text { decision-making } \\
\text { process? }\end{array}$ & $\begin{array}{l}\text { Local } \\
\text { involvement } \\
\text { projects are } \\
\text { implemented } \\
\text { through non-profit } \\
\text { organizations } \\
\text { such as CDCs, } \\
\text { Foundations, } \\
\text { CDFIs, CDPs }\end{array}$ & $\begin{array}{l}\text { Local } \\
\text { involvement } \\
\text { projects are } \\
\text { implemented } \\
\text { through non-profit } \\
\text { built ad hoc for a } \\
\text { specific aim, such } \\
\text { as Foundations. }\end{array}$ \\
\hline 2 & $\begin{array}{l}\text { Governance } \\
\text { • PPP }\end{array}$ & $\begin{array}{l}\text { - Who are/were the key } \\
\text { players involved in the } \\
\text { strategy development } \\
\text { (stakeholders, different } \\
\text { levels of government, } \\
\text { universities, and } \\
\text { non-governmental } \\
\text { institutions, among } \\
\text { others)? How were they } \\
\text { selected and through } \\
\text { what methods? } \\
\text { - How does the place-based } \\
\text { approach intent to } \\
\text { stimulate interactions and } \\
\text { cooperation between the } \\
\text { public and private sector? }\end{array}$ & $\begin{array}{l}\text { Public-Private } \\
\text { Partnerships } \\
\text { initiatives vary in } \\
\text { sizes and } \\
\text { objectives. they } \\
\text { are focused in } \\
\text { rebuilding urban } \\
\text { spaces, and the } \\
\text { relationships } \\
\text { between public } \\
\text { and private is } \\
\text { stable and strong. }\end{array}$ & $\begin{array}{l}\text { Public-Private } \\
\text { Partnerships are } \\
\text { weak, their } \\
\text { creation process is } \\
\text { still ongoing and } \\
\text { they are strongly } \\
\text { affected by the } \\
\text { public sector (or } \\
\text { they are } \\
\text { public-sector } \\
\text { led?) }\end{array}$ \\
\hline 3 & Job creation & $\begin{array}{l}\text { - Does the place-based } \\
\text { approach enable to create } \\
\text { and retain job at local } \\
\text { level? }\end{array}$ & $\begin{array}{l}\text { Several case } \\
\text { studies showed } \\
\text { that place-based } \\
\text { approach can } \\
\text { contribute to } \\
\text { foster job creation } \\
\text { and job retention. }\end{array}$ & $\begin{array}{l}\text { Place-based } \\
\text { approach, by } \\
\text { means of cluster } \\
\text { projects, } \\
\text { contributed to job } \\
\text { creation and } \\
\text { added value for } \\
\text { the companies. }\end{array}$ \\
\hline
\end{tabular}




\begin{tabular}{|c|c|c|c|c|}
\hline 4 & $\begin{array}{l}\text { Smart } \\
\text { Specialization }\end{array}$ & $\begin{array}{l}\text { - How does } \mathrm{S}^{3} \text { affect } \\
\text { regional governance? } \\
\text { How does } \mathrm{S}^{3} \text { contribute } \\
\text { to the local development } \\
\text { process? How } \mathrm{S}^{3} \text { can } \\
\text { generate a local } \\
\text { competitive advantage? }\end{array}$ & $\begin{array}{l}\text { Critical } \\
\text { assessment of the } \\
\text { federal system of } \\
\text { innovation from } \\
\text { regional } \\
\text { perspective. } \\
\text { Large clusters and } \\
\text { world class } \\
\text { universities. }\end{array}$ & $\begin{array}{l}\text { Fragmented in } \\
\text { different national } \\
\text { systems of } \\
\text { research and } \\
\text { innovation. } \\
\text { Absence } \\
\text { unrestricted } \\
\text { competition. } \\
\text { Peripheral regions } \\
\text { lack of a regional } \\
\text { system capable to } \\
\text { absorb knowledge } \\
\text { spillovers. }\end{array}$ \\
\hline 5 & $\begin{array}{l}\text { Training } \\
\text { \&Education }\end{array}$ & $\begin{array}{l}\text { - Are research and } \\
\text { educational activities } \\
\text { undertaken r by } \\
\text { universities, research } \\
\text { centers located in the } \\
\text { region? }\end{array}$ & $\begin{array}{l}\text { The gap between } \\
\text { state and federal } \\
\text { programs and } \\
\text { local community } \\
\text { is filled through } \\
\text { specific programs } \\
\text { which imply } \\
\text { neighborhood } \\
\text { involvement and } \\
\text { citizens training } \\
\text { and education. } \\
\text { The main actors } \\
\text { are large } \\
\text { community } \\
\text { development } \\
\text { organizations, } \\
\text { with several key } \\
\text { university, } \\
\text { industry, and } \\
\text { corporate } \\
\text { partners. }\end{array}$ & $\begin{array}{l}\text { Cooperation } \\
\text { between regional } \\
\text { sector } \\
\text { associations and } \\
\text { clusters } \\
\text { contributed to } \\
\text { develop joint } \\
\text { training programs } \\
\text { to meet the } \\
\text { demand for skills } \\
\text { in specific sectors, } \\
\text { involving a } \\
\text { variety a } \\
\text { professionals. }\end{array}$ \\
\hline
\end{tabular}

The information obtained on the Table 1 . are based partly on case studies conducted by the CLUDs project, and partly on different independent European case studies, and are based exclusively on our deductions from the case studies readings. The evaluations questions are the result of the knowledge of the different policy areas considered above, with the aim of understanding how differently two countries like EU and US can deal with economic and local development issues.

\section{Conclusions}

Both the European Union and the United States of America work to develop specific policies and strategies in order to improve the existing opportunities, change economic institutions, and offer new plans leading the countries to the future success and efficacy in the world.

In the US, private partnerships and organizations play a crucial role in the decision making process. On the other side, European countries implement development policies in the form of territorial and 
urban projects promoted mostly (and in many cases, exclusively) by the public sector, with the result of a mismatch between the objectives of economic development and wealth of citizens, and the goals of private entities. From this perspective, the American experience should be considered as a landmark. EU member states should pay much attention to the role of private actors in creating effective policies, while strengthening Public-Private Partnerships and non-profit organizations presence in the European context should be acknowledged as a necessity and not an option.

\section{References}

[1] F. Barca: An Agenda for a Reformed Cohesion Policy, A place-based approach to meeting European Union challenges and expectations, Report prepared at the request of Danuta Hübner, Commissioner for Regional Policy (2009)

[2] J. Tomaney: Place-Based Approaches to Regional Development: Global Trends and Australian Implications, A report for the Australian Business Foundation, OECD (2010), p.10

[3] J.O. Farnum, L.E. Kruger, Place-based Planning: Innovations and Applications from four Western Forests, Portland (2008), p.3

[4] K. CL. Gudrun, B. Pleskovic: Spatial Disparities and Development Policy, Workshop Series World Bank, Berlin (2009), p. 250

[5] N. Cattan: Cities and networks in Europe. A critical approach of polycentrism, Hors collection John Libbey, UK (2007), p. 78

[6] Commission of the European Communities 2012. Regulation of the European Parliament and of the Council, COM(12)496, Annex 1, point 3.3.2. Brussels (2012), pp . C 17-61

[7] Common Guidance of the European Commission, Community Led-Local Development in European Structural and Investment Funds, Draft Version (2013), pp. 4-60

[8] E. Baier, H. Kroll, A. Zenker: Templates of smart specialisation: Experiences of place-based regional development strategies in Germany and Austria, (Working Papers Firms and Region No. R5/2013), ISI Karlsruhe, Fraunhofer (2013)

[9] A.C. Vidal, W.D. Keating: Community Development: current issues and emerging challenges. In: Journal of Urban Affairs, Vol.26 Issue 2, (2004), pp.125-137

[10] J. De Filippis, S. Saegert, The Community Development Reader, $2^{\text {nd }}$ edition, Routledge, New York (2012)

[11] The CLUDs Network: First Scientific Report, Economic Development Strategies - the Role of Public Private Partnership, (2012)

[12] R. Ortega-Argilés: Economic Transformation Strategies, Smart Specialization Case Studies, University of Groningen (2012) 